\title{
THE LIZARD-START PROBLEM
}

SIR,-It was with special interest that I have read the article on the LizardStart Problem by Mr. J. B. Scrivenor in the last volume of the Geological Magazine, since I have been working this year on the structural petrology of the Start area and hope to proceed shortly to comparative work in the Lizard. The fabric of the Start schists shows throughout the area a wellmarked preferred orientation of mineral components, the most conspicuous expression of this in the field being a prominent lineation seen in both the mica-schist and green-schist groups. In the mica-schists the linear structure is so pronounced that "logs" resulting from the disintegration of the schists are in some places set on end to build boundary fences to the fields. Laboratory study of the microfabric is as yet incomplete, but it is clear that this megascopic lineation is related to extreme grain elongation and to a girdle fabric. From Bolt Tail in the west to Start Point in the east the lineation never deviates far from a West-East direction, and pitches uniformly westerly in conformity with the axes of the pitching anticlinorium which is the dominant structural feature of the area. These findings would appear to afford no support for the suggestion recently put forward by Dr. E. M. Anderson (Quart. Journ. Geol. Soc., 1948, civ, 125) that " a rather fundamental mistake has hitherto usually been made in the interpretation of petrofabric structures ".

A further marked feature of the fabric is the far-reaching development of post-crystalline deformation ; it is possible that careful study of the symmetry of this deformation in relation to that of the primary tectonite fabric may be a valuable auxiliary in helping to "guide us to a solution of the question whether the mica-schists ... are Devonian or older " (J. B. S., ibid., p. 385). DEPARTMENT OF GEOLOGY,

BRISTOL UNIVERSITY.

F. C. Phillips. 3rd January, 1950.

\section{REVIEWS}

Physical Geology. By W. J. Miller. pp. ix and 482 with 397 text-figs. Van Nostrand Co. Inc., New York. Fifth Edition, 1949. Price 32s. before devaluation.

An Introduction to Physical Geology with special reference to North America is a companion volume to the author's Historical Geology. The American market can apparently absorb several textbooks of the same general scope, price, and quality. In this edition a thorough revision of text and figures has been made and the order of treatment has been altered so as to begin with the materials of the earth's crust: minerals, rocks, diastrophism, structure and volcanoes. This is followed by the work of the principal agents of gradation, then land forms, and finally the inevitable chapter on Economic Geology and an appendix on minerals. This book is distinguished from its competitors by this different order and by the enumeration in small type of illustrative detail of various phenomena, so adding more reference value to the usual glossy text.

W. B. H.

A Student's Introduction to Geology Mainly Physical. By G. M. DAvIES. pp. vii and 246 with 175 text-figs. Thos. Murby and Co., 1949. Price 18s.

Twenty-nine short chapters with the usual headings, including seven on stratigraphy, outline the barest essentials without wasting words and without avoiding dogmatism. This is intended as a first-year text and one would wonder what the lectures would be about if they did not more than cover 